\title{
Upstream therapy with statin and recurrence of atrial fibrillation after electrical cardioversion. Review of the literature and meta-analysis
}

\author{
Lorenzo Loffredo*, Francesco Angelico, Ludovica Perri and Francesco Violi
}

\begin{abstract}
Background: Atrial fibrillation (AF) is the most common sustained arrhythmia observed in clinical practice. Electrical cardioversion (EC) is commonly used to restore and maintain sinus rhythm but it is characterized by high rate of recurrences. Several trials analyzed the effects of statins to reduce the recurrences in AF with contradictory results.

Methods: We performed a meta-analysis of the interventional trials with statins in patients with persistent AF to evaluate recurrences after EC. Only randomized controlled trials were included in the analysis. Data sources included: Medline, ISI Web of Science, SCOPUS and Cochrane database (up to June 2012). Data extraction was performed by three authors. Study-specific odds ratios (ORs) were combined using fixed-effects model.

Results: Six studies with 515 patients were included in the analysis. Statins used in the selected trials were: atorvastatin (at dosages ranging from 10 to $80 \mathrm{mg} /$ day), pravastatin (40 mg/day) and rosuvastatin (20 mg/day). AF recurrence after EC occurred in 108/258 (41.8\%) of patients treated with statins and in 132/257 (51.3\%) patients not on treatment with statins. Compared with control, recurrences were significantly reduced with statin treatment (O.R.: 0.662; 95\% C.I., 0.45-0.96; $\mathrm{p}=0.03$ ); statin treatment was associated with an absolute risk reduction of 0.095 and a number needed to treat of 11 .
\end{abstract}

Conclusions: This review suggests that statin therapy was significantly associated with a decreased risk of recurrence in patients with persistent AF after $E C$.

Keywords: Atrial fibrillation, Statin, Electrical cardioversion

\section{Background}

Atrial fibrillation (AF) is the most common sustained arrhythmia observed in clinical practice with prevalence increasing with age [1]. Patients with AF have about 5 -fold increase of stroke risk, which is prevalently dependent on thrombosis occurring in the left atrium or left atrium appendage [2]. Restoration of sinus rhythm in patients with AF is a strategy to prevent the cardiovascular and thromboembolic complications of this arrhythmia [3].

Persistent AF is one presentation of the disease. AHA guidelines defined persistent AF when the arrhythmia sustains beyond 7 days [1] and usually terminates with

\footnotetext{
* Correspondence: lorenzo.loffredo@uniroma1.it

I Clinica Medica, Sapienza University of Rome, Viale del Policlinico 155, Rome 00161, Italy
}

pharmacological therapy or direct-current electrical cardioversion (EC) [1].

Sinus rhythm restoration in AF is not associated to reduction of thromboembolic complications and mortality [4-6]. However, the maintenance of sinus rhythm, in patients with $\mathrm{AF}$, gives potential benefits such as the prevention of electrical and structural remodeling of the atria, improved haemodynamic function, amelioration of symptoms, and improvement for quality life [7].

EC is commonly used, with antiarrhythmic drugs, to restore and maintain sinus rhythm [1]. These therapies are limited by low efficacy [8]; one week after successful EC, about $25 \%$ of patients will experience a recurrence of the disease [8]. Besides research efforts to improve the efficacy of antiarrhythmic agents, there is a growing interest to the "upstream" therapy of AF $[9,10]$. Potential upstream therapies, which seek to inhibit the formation 
and evolution of the substrate for AF, include statins and angiotensin-converting enzyme inhibitors. Statins possess anti-inflammatory and antioxidant effects which can counteract inflammatory and oxidative stress pathways which are believed to contribute to the pathogenesis of AF $[11,12]$.

The relationship between statin therapy and AF recurrence in patients with AF has been evaluated by several meta-analyses, which provided, however, conflicting results[13-16]. These meta-analyses, however, did not specifically investigate if statins reduce recurrence in patients with persistent AF undergoing $\mathrm{EC}$ as different clinical settings associated with AF were included in the meta-analyses. Therefore, the main objective of our study was to systematically review and analyze the effect of statin therapy on recurrence of AF after EC.

\section{Methods}

\section{Eligibility criteria}

Types of studies

Randomized clinical trials (RCTs) studying the effect of statins on recurrence of AF. No language, publication date, or publication status restrictions were imposed.

\section{Types of participants}

Patients of any age, with persistent AF treated with EC, were considered. Patients were excluded from this review if $\mathrm{AF}$ was treated with surgical interventions.

\section{Types of outcome measures}

The rationale of this review was to analyze the clinical effectiveness of statins to reduce the recurrences after $\mathrm{EC}$ in patients with persistent AF.

Because EC is unsuccessful at converting AF to sinus rhythm in some patients we performed a per-protocol analysis, including only the patients who restored to normal rhythm.

\section{Information sources}

The studies were identified by searching electronic databases. This search was applied to Medline, ISI Web of Science, SCOPUS and Cochrane database. The last search was run on 9 June 2012. Reference lists of all studies included in the present systematic review were screened for potential additional eligible studies.

\section{Search}

Studies were identified by searching Medline, ISI Web of Science, SCOPUS and Cochrane Database by crossing each of the following keywords:

- statin

- recurrence

- atrial fibrillation
- electrical cardioversion

- randomized controlled trials

\section{Study selection}

Two authors (L.L., L.P.) independently reviewed all selected titles and abstracts. Studies were excluded if the title and/or abstract was not appropriate for the aim of our review. Full texts were subsequently obtained for eligible studies or when the relevance of an article could not be excluded with certainty. Disagreement was resolved by consensus and by opinion of a third reviewer (F.V.), if necessary.

Studies not including a control group drawn from the same population, animal studies, or trials that exclusively reported other clinical outcomes were excluded. Case reports, editorials, commentaries, letters, review articles, guidelines or secondary prevention trials were also excluded from the analysis.

\section{Data extraction and quality assessment}

For RCTs we planned quality assessment (Table 1) by means of Jadad's scale [17] which evaluates the following three study characteristics: method of randomization, method of blinding, and follow-up. To stratify RCTs, we applied the following cut-offs: a total of five points defined high quality studies; three and four points defined medium quality studies; two or less points defined low quality studies.

This review was conducted and reported according to the PRISMA (Preferred Reporting Items for Systematic Reviews and Meta-Analysis) Statement issued in 2009 [18].

\section{Statistical analysis}

To evaluate the effect of statins on recurrence of AF after EC, we allocated the results of each randomized controlled trial as dichotomous frequency data. Odds ratios (ORs) and 95\% confidence intervals (CIs) were calculated. These data were pooled using a fixed-effects model (the Mantel-Haenszel method) [19]. Statistical heterogeneity was evaluated using the $I^{2}$ statistic, which assesses the appropriateness of pooling the individual study results [17]. The $I^{2}$ value provides an estimate of the amount of variance across studies due to heterogeneity rather than chance. $I^{2}<30 \%$ indicates mild heterogeneity, 30-50\% moderate, and $>50 \%$ severe heterogeneity.

The software Comprehensive Meta Analysis (version 2.2.064, USA, 2011) supported the analysis.

\section{Results}

The search provided a total of 316 citations. Of these, 293 studies were discarded after reviewing the titles and abstracts because it appeared that these papers clearly did not meet the selection criteria (Figure 1). 
Table 1 Characteristics of the studies included in the metanalysis

\begin{tabular}{|c|c|c|c|c|c|c|c|c|c|c|c|}
\hline Author & $\begin{array}{l}\text { Number of } \\
\text { patients and } \\
\text { mean Age } \\
\text { (years) }\end{array}$ & $\begin{array}{l}\text { Males (\%) } \\
\text { statin/ } \\
\text { control } \\
\text { group }\end{array}$ & Intervention & Follow-up & $\begin{array}{l}\text { Total cholesterol } \\
\text { (TC) and LDL } \\
\text { cholesterol } \\
\text { values before } \\
\text { and after } \\
\text { treatment with } \\
\text { statin,mean } \\
\text { mg/dl and \% } \\
\text { reduction }\end{array}$ & $\begin{array}{l}\text { Co-morbidities } \\
\text { (\%) statin/ } \\
\text { control group }\end{array}$ & $\begin{array}{l}\text { Concurrent } \\
\text { Medications } \\
\text { (\%) statin/ } \\
\text { control group }\end{array}$ & $\begin{array}{l}\text { Placebo- } \\
\text { controlled/ } \\
\text { Double } \\
\text { blind }\end{array}$ & $\begin{array}{l}\text { Unsuccessful } \\
\text { Cardioversion } \\
\text { statin/control } \\
\text { group (n) }\end{array}$ & $\begin{array}{l}\text { Mean Left } \\
\text { Atrial diameter } \\
(\mathrm{mm}) \text { Statin/ } \\
\text { control group }\end{array}$ & $\begin{array}{l}\text { Jadad } \\
\text { Score }\end{array}$ \\
\hline \multirow[t]{2}{*}{$\begin{array}{l}\text { Almroth } \\
2009 \text { [21] }\end{array}$} & \multirow[t]{2}{*}{$234(65 \pm 10)$} & \multirow[t]{2}{*}{ 76/74 } & \multirow{2}{*}{$\begin{array}{l}\text { Atorvastatin } \\
80 \mathrm{mg} / \text { day } \\
\text { (started at } \\
\text { least } 14 \text { days } \\
\text { before EC) }\end{array}$} & \multirow[t]{2}{*}{30 days } & $\begin{array}{l}\text { TC:202-136 } \\
(-32.6 \%) \\
\end{array}$ & \multirow{2}{*}{$\begin{array}{l}\mathrm{H}: 47 / 48 \\
\mathrm{D}: 7 / 10 \\
\text { CAD:4/4 }\end{array}$} & \multirow{2}{*}{$\begin{array}{l}\text { B:87/80 } \\
\text { C:14/16 } \\
\text { DG:16/20 }\end{array}$} & \multirow[t]{2}{*}{ YES/YES } & \multirow[t]{2}{*}{$8 / 13$} & \multirow[t]{2}{*}{$44 / 43$} & \multirow[t]{2}{*}{5} \\
\hline & & & & & $\begin{array}{l}\mathrm{LDL}: 123-65 \\
(-52.8 \%)\end{array}$ & & & & & & \\
\hline \multirow[t]{2}{*}{$\begin{array}{l}\text { Ozaydin } \\
2006 \text { [22] }\end{array}$} & \multirow[t]{2}{*}{$48(62 \pm 11)$} & \multirow[t]{2}{*}{$71 / 50$} & \multirow{2}{*}{$\begin{array}{l}\text { Atorvastatin } \\
10 \mathrm{mg} / \text { day } \\
\text { (started } \\
48 \text { hours } \\
\text { before EC) }\end{array}$} & \multirow[t]{2}{*}{3 months } & $\begin{array}{l}\text { TC:179-151 } \\
(-15.6 \%)\end{array}$ & \multirow[t]{2}{*}{$\begin{array}{l}\text { H:42/38 } \\
\text { D:21/25 }\end{array}$} & \multirow{2}{*}{$\begin{array}{l}\text { B:33/25 } \\
\text { C:21/42 } \\
\text { DG:4/4 } \\
\text { A:8/4 } \\
P: 8 / 8\end{array}$} & \multirow[t]{2}{*}{$\mathrm{NO} / \mathrm{NO}$} & \multirow[t]{2}{*}{0} & \multirow[t]{2}{*}{$47 / 43$} & \multirow[t]{2}{*}{2} \\
\hline & & & & & $\begin{array}{l}\text { LDL:109-95 } \\
(-12.8 \%)\end{array}$ & & & & & & \\
\hline \multirow[t]{2}{*}{$\begin{array}{l}\text { Xia } \\
2009 \text { [23] }\end{array}$} & \multirow[t]{2}{*}{$64(61 \pm 8)$} & \multirow[t]{2}{*}{$69 / 63$} & \multirow{2}{*}{$\begin{array}{l}\text { Rosuvastatin } \\
10 \mathrm{mg} / \text { day } \\
\text { (started } 48 \mathrm{~h} \\
\text { before EC) }\end{array}$} & 3 months & $\begin{array}{l}\text { TC:159-131 } \\
(-17.6 \%)\end{array}$ & \multirow[t]{2}{*}{-} & \multirow{2}{*}{$\begin{array}{l}\text { B:38/31 } \\
\text { C: } 31 / 34 \\
\text { A:22/28 } \\
\text { DG:13/6 }\end{array}$} & \multirow[t]{2}{*}{$\mathrm{NO} / \mathrm{NO}$} & \multirow[t]{2}{*}{0} & \multirow[t]{2}{*}{$41 / 41$} & \multirow[t]{2}{*}{1} \\
\hline & & & & & $\begin{array}{l}\text { LDL:97-83 } \\
(-14.4 \%)\end{array}$ & & & & & & \\
\hline \multirow{3}{*}{$\begin{array}{l}\text { Tveit } \\
2004 \text { [20] }\end{array}$} & \multirow[t]{3}{*}{$114(68 \pm 10)$} & \multirow[t]{3}{*}{ 79/75 } & \multirow{3}{*}{$\begin{array}{l}\text { Pravastatin } \\
40 \mathrm{mg} / \text { day } \\
\text { (started } \\
3 \text { weeks } \\
\text { before EC) }\end{array}$} & \multirow[t]{3}{*}{6 weeks } & Mean n.s. & $\mathrm{H}: 42 / 44$ & B:67/65 & $\mathrm{NO} / \mathrm{NO}$ & $11 / 11$ & $45 / 43$ & 3 \\
\hline & & & & & TC:-22\% & $\begin{array}{l}\text { D:9/4 } \\
\text { COPD:11/11 }\end{array}$ & $\begin{array}{l}\text { C:30/28 } \\
\text { DG:25/23 }\end{array}$ & & & & \\
\hline & & & & & LDL:-33\% & CHD:9/12 & $\begin{array}{l}F: 6 / 4 \\
A: 2 / 4\end{array}$ & & & & \\
\hline $\begin{array}{l}\text { Demir } \\
2011 \text { [25] }\end{array}$ & $44(61 \pm 10)$ & $48 / 44$ & $\begin{array}{l}\text { Atorvastatin } \\
40 \text { mg/day }\end{array}$ & 2 months & $\begin{array}{l}\text { TC:174-129 } \\
(-25.8 \%)\end{array}$ & $\begin{array}{l}\mathrm{H}: 74 / 52 \\
\mathrm{D}: 8 / 4\end{array}$ & $\begin{array}{l}\text { A:91/87 } \\
\text { P:4/8 }\end{array}$ & $\mathrm{NO} / \mathrm{NO}$ & $1 / 1$ & $42 / 43$ & 1 \\
\hline & & & $\begin{array}{l}\text { (started } \\
3 \text { weeks } \\
\text { before EC) }\end{array}$ & & $\begin{array}{l}\text { LDL:112-62 } \\
(-44.6 \%)\end{array}$ & $\begin{array}{l}\text { S:17/17 } \\
\text { CHD:21/13 }\end{array}$ & C:22/26 & & & & \\
\hline $\begin{array}{l}\text { Negi } \\
2011 \text { [24] }\end{array}$ & $64(55 \pm 12)$ & $82 / 84$ & $\begin{array}{l}\text { Atorvastatin } \\
80 \mathrm{mg} / \text { day } \\
\text { (started at } \\
\text { randomization: } \\
0-7 \text { days } \\
\text { before EC) }\end{array}$ & 12 months & $\begin{array}{l}\text { TC:183-142 } \\
(-22.4 \%)\end{array}$ & $\begin{array}{l}\text { H:52/49 } \\
\text { D:12/3.2 } \\
\text { S:24/16 } \\
\text { CHD:12/13 }\end{array}$ & B: 49/68 & YES/YES & - & $46 / 46$ & 4 \\
\hline
\end{tabular}

$H$, hypertension; $D$, diabetes mellitus; $S$ : smoking; COPD, chronic obstructive pulmonary disease; $C H D$, coronary heart disease; $B$, beta blockers; $C$, calcium channel blockers; $D G$, Digitoxin; $F$, Flecainide; $A$, Amiodarone; $P$, Propafenone; $n$.s., not specified. 
A total of 6 studies [20-25] met the inclusion criteria and were included in this systematic review.

The study identification and selection progression is summarized in Figure 1.

All studies were written in English. The 6 studies ranged in size from 44 to 234 patients for a total of 568 patients (Table 1). Three out of the studies were low quality studies according to Jadad's score (Table 1).

Clinical characteristics of the study populations are illustrated in the Table 1 . All the trials included patients with an average age $>50$ years (Table 1 ). Compared to females, males were more frequently distributed in all trials (Table 1), except one, ranging from 48 to $82 \%$ (mean: $70.8 \%$ ) in statin group and from 44 to $84 \%$ (mean: $65 \%$ ) in control group.

Only two trials, conducted by Almroth et al. [21] and Negi et al. [24], were double-blind and placebo-controlled studies (Table 1).

Intervention treatment started from randomization day to 3 weeks before EC (Table 1).

Left atrial diameter ranged from 41 to $47 \mathrm{~mm}$ (mean: $44.6 \mathrm{~mm}$ ) in statin group and from 41 to $46 \mathrm{~mm}$ (mean: $43.2 \mathrm{~mm}$ ) in control group (Table 1).

The rate of previous coronary heart disease (CHD) was specified in four studies [20,21,24,25].

Statins used in the selected trials were: atorvastatin (at dosages ranging from 10 to $80 \mathrm{mg} /$ day), pravastatin (40 mg/day) and rosuvastatin (20 mg/day) (Table 1$)$.

The mean follow-up of the studies ranged from 30 days to 1 year (mean 3.7 \pm 4.1 months) (Table 1 ).
CHADS score [8] was reported only in one study [21]. Concomitant treatments and comorbidities are reported in Table 1.

Total cholesterol in the treated groups lowered from $15 \%$ to $32 \%$ according to the different type and dosage of statin (Table 1).

The rate of recurrences was different, according to the follow-up and to the treatment, among the studies ranging from as high as $66.6 \%$ (22/33 patients) to as low as $12.5 \%$ (3/24 patients) in statin groups and from as high as $83.8 \%(26 / 31$ patients) to as low as $13.6 \%(3 / 22$ patients) in control groups (Table 1).

AF recurrence after EC occurred in 108/258 (41.8\%) of patients treated with statins and in 132/257 (51.3\%) controls. Statins significantly reduced the recurrences (O.R.: 0.662; 95\% C.I., 0.45-0.96; $\mathrm{p}=0.03$ ) (Figure 2) with an absolute risk reduction (ARR) of 0.095 and a number needed to treat (NNT) of 11 . Heterogeneity across the studies[26] was moderate $\left(\mathrm{I}^{2}=50, \mathrm{p}=0.062\right)$.

\section{Discussion}

This systematic review reports, for the first time, that upstream therapy with statins may be useful for the prevention of recurrence in patients with persistent AF who had undergone successful EC.

Previous meta-analyses studied the relationship between statins and AF, with inconclusive results. However they did not distinguish among the different types of AF (e.g. paroxysmal) [13-16], since observational studies

Studies' selection progression.

316 Potentially relevant studies

identified and screened for retrieval

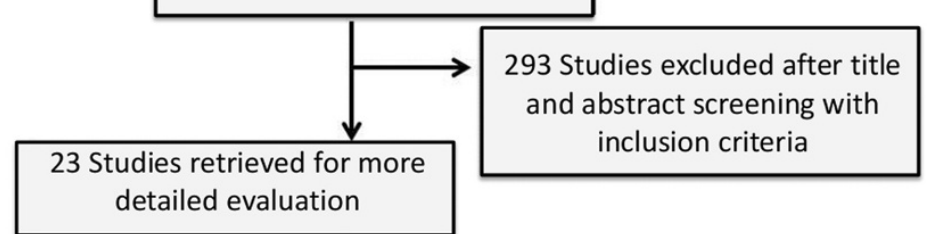

Studies excluded $(n=17)$

- The studies were not RCT ( $n=16)$

- The study did not report the rate of recurrence after $\mathrm{EC}(n=1)$

6 studies included in the meta-analysis

Figure 1 Flow diagram of study selection. 
[13] or cardiac surgical interventions, as coronary artery bypass grafting (CABG)[14,16], or patients undergone to EC $[14,15]$. Thus, these meta-analyses did not specifically address the question as to whether statin treatment is able to reduce or prevent recurrences in patients with persistent AF undergoing EC [13-16].

This issue may be clinically relevant as statins have anti-inflammatory properties and inhibit specific pathways generating oxidative stress, which are believed to trigger AF. Indeed, inflammation may interfere with the electrophysiological and structural changes of AF [27]. The presence of systemic inflammation, as shown by high serum levels of high-sensitivity $C$ reactive protein (CRP) and interleukins 6 and 8, has been associated with AF [27]. Also, Dernellis et al. demonstrated that treatment with atorvastatin (initiated at a minimum of 20 $\mathrm{mg} /$ day and increased to a maximum of $40 \mathrm{mg} /$ day) lowered CRP levels coincidentally with reduced recurrence in patients with paroxysmal AF [28]. Same results were detected by Negi et al. in atorvastatin $(80 \mathrm{mg} /$ day)- treated persistent AF patients, who underwent EC [24]. Oxidative stress plays also a pivotal role in inducing and maintaining AF $[27,29]$. The nicotinamide adenine dinucleotide phosphate (NADPH) oxidase is considered the most important cellular source of reactive oxygen species (ROS) in humans [30,31]; this enzyme is suggested to be implicated in functional changes of the atria which may favor AF [30]. Indeed, studies in humans have shown that myocytes from the right atrial appendage produce a significant amount of ROS through activation of NOX2, the catalytic subunit of NADPH oxidase [32]. Furthermore, NOX2 activation was observed in experimental models of AF [33] and in patients with postsurgery paroxysmal AF while it was within normal range in patients with permanent AF [33]. In accordance with this finding a serum activity of NOX2 was up-regulated only in patients with paroxysmal-persistent AF [34] and low serum levels of vitamin E, a known antioxidant [35], and associated with AF recurrence in patients who underwent EC [12]. As statin therapy inhibits ROS generation via down-regulation of NOX2 [33,36] and increase the serum levels of vitamin E [37], it would be tempting to speculate that inhibition of NOX2generated ROS may hamper recurrence in patients with paroxysmal/persistent AF undergoing EC.

Therefore, down-regulation of NOX2 and inhibition of CRP may represent a plausible mechanism accounting for the beneficial effects observed by statin treatment in our meta-analysis. The analysis of six RCT demonstrated, in fact, an AF recurrence rate of $51.3 \%$ in control group and of $41.8 \%$ in statin-treated group with a relative risk reduction of $19 \%$. The absolute risk reduction $(9.5 \%)$ resulted in a number needed to treat of 11 patients with persistent AF.

This meta-analysis has the following limitations. Only two studies are placebo-controlled [21], [24] and all the remaining are open-label studies. The sample size of the included studies is low, ranging from 44 to 222 patients. The Jadad score, used to evaluate the quality of the trials, is low $(<3)$ in about $50 \%$ of the studies included in the meta-analysis (Table 1). Furthermore, the female gender was less frequent with an average of $30 \%$ in the different studies. Finally, there is a great heterogeneity for cholesterol levels before and after treatment, statin type and dosage among the studies included in this analysis (Table 1).

\section{Conclusions}

The results of this meta-analysis are of potential interest as they could represent a useful background to plan future studies to test the hypothesis that upstream therapy with statins may be beneficial to prevent AF recurrence in patients with persistent AF who undergo successful EC.

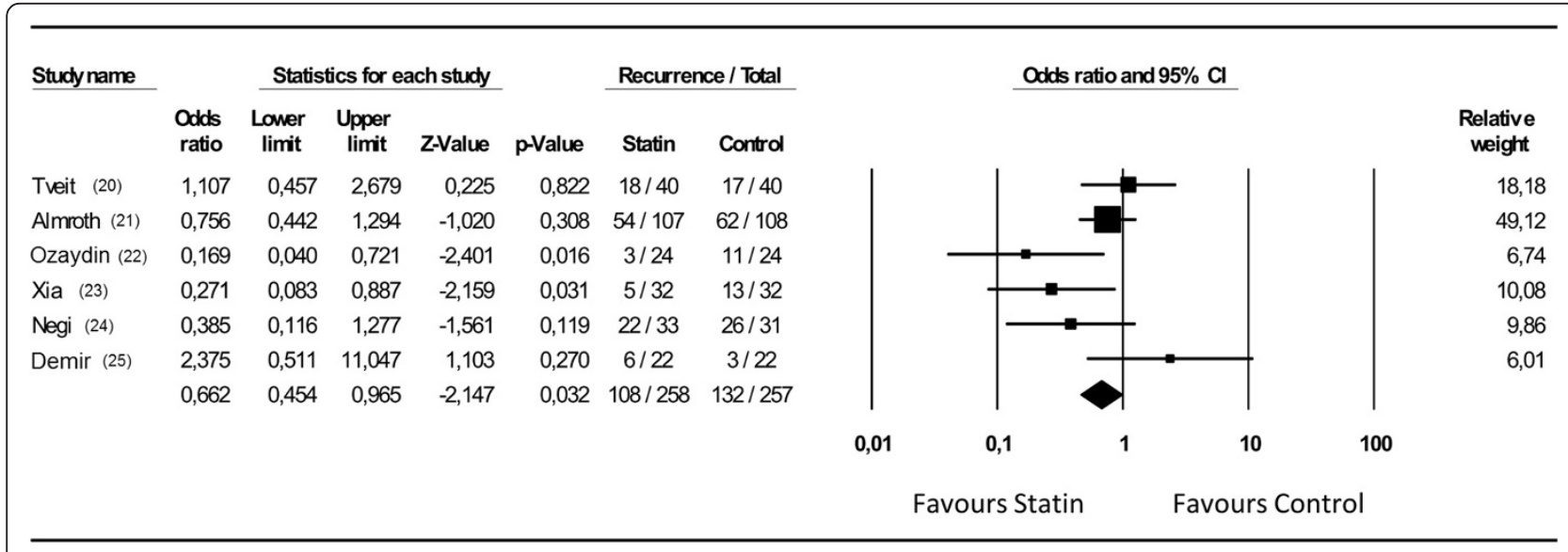

Figure 2 Effect of statins on recurrences of atrial fibrillation. 


\section{Abbreviations}

AF: Atrial fibrillation; EC: Electrical cardioversion; CHD: Coronary heart disease; $\mathrm{RCTs}$ : Randomized clinical trials; CRP: C reactive protein;

NADPH: Nicotinamide adenine dinucleotide phosphate; ROS: Reactive oxygen species; CABG: Coronary artery bypass grafting.

\section{Competing interests}

All the authors declare that they have no competing interests in relation to this manuscript.

\section{Authors' contributions}

All authors contributed to the conception and design of the study, participated in writing the manuscript, and approved the final draft. $L L$ and LP undertook the literature search and retrieval of publications. $L L$ and $L P$ performed statistical analysis. All authors read and approved the final manuscript.

Received: 11 September 2012 Accepted: 15 November 2012 Published: 21 November 2012

\section{References}

1. Wann LS, Curtis AB, Ellenbogen KA, Estes NA 3rd, Ezekowitz MD, Jackman WM, January CT, Lowe JE, Page RL, Slotwiner DJ, et al: 2011 ACCF/AHA/HRS focused update on the management of patients with atrial fibrillation (update on dabigatran): a report of the american college of cardiology foundation/american heart association task force on practice guidelines. J Am Coll Cardiol 2011, 57(11):1330-1337.

2. Wolf PA, Dawber TR, Thomas HE Jr, Kannel WB: Epidemiologic assessment of chronic atrial fibrillation and risk of stroke: the Framingham study. Neurology 1978, 28(10):973-977.

3. Sherman DG: Stroke prevention in atrial fibrillation: pharmacological rate versus rhythm control. Stroke 2007, 38(2 Suppl):615-617.

4. Corley SD, Epstein AE, DiMarco JP, Domanski MJ, Geller N, Greene HL, Josephson RA, Kellen JC, Klein RC, Krahn AD, et al: Relationships between sinus rhythm, treatment, and survival in the atrial fibrillation follow-up investigation of rhythm management (AFFIRM) Study. Circulation 2004, 109(12):1509-1513.

5. Wyse DG, Waldo AL, DiMarco JP, Domanski MJ, Rosenberg Y, Schron EB, Kellen JC, Greene HL, Mickel MC, Dalquist JE, et al: A comparison of rate control and rhythm control in patients with atrial fibrillation. N Engl J Med 2002, 347(23):1825-1833.

6. Hagens VE, Ranchor AV, Van Sonderen E, Bosker HA, Kamp O, Tijssen JG, Kingma JH, Crijns HJ, Van Gelder IC: Effect of rate or rhythm control on quality of life in persistent atrial fibrillation. Results from the Rate Control Versus Electrical Cardioversion (RACE) Study. J Am Coll Cardiol 2004, 43(2):241-247.

7. Chung MK: Randomized trials of rate vs. rhythm control for atrial fibrillation. J Interv Card Electrophysiol 2004, 10(Suppl 1):45-53.

8. Fuster V, Ryden LE, Cannom DS, Crijns HJ, Curtis AB, Ellenbogen KA, Halperin JL, Kay GN, Le Huezey JY, Lowe JE, et al: 2011 ACCF/AHA/HRS focused updates incorporated into the ACC/AHA/ESC 2006 guidelines for the management of patients with atrial fibrillation: a report of the american college of cardiology foundation/american heart association task force on practice guidelines developed in partnership with the european society of cardiology and in collaboration with the european heart rhythm association and the heart rhythm society. J Am Coll Cardiol 2011, 57(11):e101-e198.

9. Savelieva I, Kakouros N, Kourliouros A, Camm AJ: Upstream therapies for management of atrial fibrillation: review of clinical evidence and implications for European society of cardiology guidelines. Part l: primary prevention. Europace 2011, 13(3):308-328.

10. Savelieva I, Kakouros N, Kourliouros A, Camm AJ: Upstream therapies for management of atrial fibrillation: review of clinical evidence and implications for European society of cardiology guidelines. Part II: secondary prevention. Europace 2011, 13(5):610-625.

11. Li J, Solus J, Chen Q, Rho YH, Milne G, Stein CM, Darbar D: Role of inflammation and oxidative stress in atrial fibrillation. Hear Rhythm 2010 7(4):438-444.

12. Ferro $D$, Franciosa $P$, Cangemi $R$, Carnevale $R$, Pignatelli $P$, Loffredo $L$, Perri $L$, Catasca E, Violi F: Serum levels of vitamin E are associated with early recurrence of atrial fibrillation after electric cardioversion. Circ Arrhythm Electrophysiol 2012, 5(2):327-333.

13. Dentali F, Gianni M, Squizzato A, Ageno W, Castiglioni L, Maroni L, Hylek EM, Grandi AM, Cazzani E, Venco A, et al: Use of statins and recurrence of atrial fibrillation after catheter ablation or electrical cardioversion. A systematic review and meta-analysis. Thromb Haemost 2011, 106(2):363-370.

14. Rahimi K, Emberson J, McGale P, Majoni W, Merhi A, Asselbergs FW, Krane V, Macfarlane PW: Effect of statins on atrial fibrillation: collaborative metaanalysis of published and unpublished evidence from randomised controlled trials. BMJ 2011, 342:d1250.

15. Wang Z, Zhang Y, Gao M, Wang J, Wang Q, Wang X, Su L, Hou Y: Statin therapy for the prevention of atrial fibrillation: a meta-analysis of randomized controlled trials. Pharmacotherapy 2011, 31(11):1051-1062.

16. Fauchier L, Pierre B, de Labriolle A, Grimard C, Zannad N, Babuty D: Antiarrhythmic effect of statin therapy and atrial fibrillation a meta-analysis of randomized controlled trials. J Am Coll Cardiol 2008 51(8):828-835

17. Jadad AR, Moore RA, Carroll D, Jenkinson C, Reynolds DJ, Gavaghan DJ, McQuay HJ: Assessing the quality of reports of randomized clinical trials: is blinding necessary? Control Clin Trials 1996, 17(1):1-12.

18. Moher D, Liberati A, Tetzlaff J, Altman DG: Preferred reporting items for systematic reviews and meta-analyses: the PRISMA statement. PLoS Med 2009, 6(7):e1000097.

19. Mantel N, Haenszel W: Statistical aspects of the analysis of data from retrospective studies of disease. J Natl Cancer Inst 1959, 22(4):719-748.

20. Tveit A, Grundtvig M, Gundersen T, Vanberg P, Semb AG, Holt E, Gullestad L: Analysis of pravastatin to prevent recurrence of atrial fibrillation after electrical cardioversion. Am J Cardiol 2004, 93(6):780-782.

21. Almroth H, Hoglund N, Boman K, Englund A, Jensen S, Kjellman B, Tornvall $P$, Rosenqvist M: Atorvastatin and persistent atrial fibrillation following cardioversion: a randomized placebo-controlled multicentre study. Eur Heart J 2009, 30(7):827-833.

22. Ozaydin M, Varol E, Aslan SM, Kucuktepe Z, Dogan A, Ozturk M, Altinbas A: Effect of atorvastatin on the recurrence rates of atrial fibrillation after electrical cardioversion. Am J Cardio/ 2006, 97(10):1490-1493.

23. Xia W, Yin Z, Li J, Song Y, Qu X: Effects of rosuvastatin on asymmetric dimethylarginine levels and early atrial fibrillation recurrence after electrical cardioversion. Pacing Clin Electrophysio/ 2009, 32(12):1562-1566.

24. Negi S, Shukrullah I, Veledar E, Bloom HL, Jones DP, Dudley SC: Statin therapy for the prevention of atrial fibrillation trial (SToP AF trial). J Cardiovasc Electrophysiol 2011, 22(4):414-419.

25. Demir K, Can I, Koc F, Vatankulu MA, Ayhan S, Akilli H, Aribas A, Alihanoglu $Y$, Altunkeser BB: Atorvastatin given prior to electrical cardioversion does not affect the recurrence of atrial fibrillation in patients with persistent atrial fibrillation who are on antiarrhythmic therapy. Med Princ Pract 2011, 20(5):464-469

26. Higgins JP, Thompson SG: Quantifying heterogeneity in a meta-analysis. Stat Med 2002, 21(11):1539-1558.

27. Tamargo J, Caballero R, Gomez R, Nunez L, Vaquero M, Delpon E: Lipidlowering therapy with statins, a new approach to antiarrhythmic therapy. Pharmacol Ther 2007, 114(1):107-126.

28. Dernellis J, Panaretou M: Effect of C-reactive protein reduction on paroxysmal atrial fibrillation. Am Heart J 2005, 150(5):1064

29. Neuman RB, Bloom HL, Shukrullah I, Darrow LA, Kleinbaum D, Jones DP, Dudley SC Jr: Oxidative stress markers are associated with persistent atrial fibrillation. Clin Chem 2007, 53(9):1652-1657.

30. Cave AC, Brewer AC, Narayanapanicker A, Ray R, Grieve DJ, Walker S, Shah AM: NADPH oxidases in cardiovascular health and disease. Antioxid Redox Signal 2006, 8(5-6):691-728.

31. Loffredo L: Chronic granulomatous disease. Intern Emerg Med 2011 6(Suppl 1):125-128.

32. Kim YM, Guzik TJ, Zhang YH, Zhang MH, Kattach H, Ratnatunga C, Pillai R, Channon KM, Casadei B: A myocardial Nox2 containing NAD(P)H oxidase contributes to oxidative stress in human atrial fibrillation. Circ Res 2005, 97(7):629-636.

33. Reilly SN, Jayaram R, Nahar K, Antoniades C, Verheule S, Channon KM, Alp NJ, Schotten U, Casadei B: Atrial sources of reactive oxygen species vary with the duration and substrate of atrial fibrillation: implications for the antiarrhythmic effect of statins. Circulation 2011, 124(10):1107-1117. 
34. Cangemi R, Celestini A, Calvieri C, Carnevale R, Pastori D, Nocella C, Vicario T, Pignatelli P, Violi F: Different behaviour of NOX2 activation in patients with paroxysmal/persistent or permanent atrial fibrillation. Heart 2012, 98(14):1063-1066.

35. Violi F, Loffredo L, Musella L, Marcoccia A: Should antioxidant status be considered in interventional trials with antioxidants? Heart 2004, 90(6):598-602.

36. Antoniades $\mathrm{C}$, Demosthenous M, Reilly S, Margaritis M, Zhang MH, Antonopoulos A, Marinou K, Nahar K, Jayaram R, Tousoulis D, et al: Myocardial redox state predicts in-hospital clinical outcome after cardiac surgery effects of short-term pre-operative statin treatment. J Am Coll Cardiol 2012, 59(1):60-70.

37. Cangemi R, Loffredo L, Carnevale R, Perri L, Patrizi MP, Sanguigni V, Pignatelli P, Violi F: Early decrease of oxidative stress by atorvastatin in hypercholesterolaemic patients: effect on circulating vitamin E. Eur Heart J 2008, 29(1):54-62.

doi:10.1186/1471-2261-12-107

Cite this article as: Loffredo et al:: Upstream therapy with statin and recurrence of atrial fibrillation after electrical cardioversion. Review of the literature and meta-analysis. BMC Cardiovascular Disorders 2012

$12: 107$

\section{Submit your next manuscript to BioMed Central and take full advantage of:}

- Convenient online submission

- Thorough peer review

- No space constraints or color figure charges

- Immediate publication on acceptance

- Inclusion in PubMed, CAS, Scopus and Google Scholar

- Research which is freely available for redistribution 